\title{
OPTIMIZATION OF PATHOGENETIC THERAPY IN PATIENTS WITH CHRONIC OBSTRUCTIVE LUNG DISEASE
}

DOI: 10.36740/WLek202004128

\author{
Maksym M. Potyazhenko, Kostiantyn Ye. Ishcheikin, Tetiana V. Nastroga, Nina L. Sokolyuk, Oksana Ye. Kitura, \\ Inesa M. Gorodnytska \\ UKRAINIAN MEDICAL STOMATOLOGICAL ACADEMY, POLTAVA, UKRAINE
}

\begin{abstract}
The aim of the study is to increase the effectiveness of the treatment of exacerbation of COPD group B GOLD II with the use of combined therapy of the combined drug PulmoBRIZ containing two components - ambroxol and acetylcysteine and the course of halotherapy.

Materials and methods: We observed 60 patients with COPD B, GOLD II. They were divided into two groups: the first - the main ( $n=30)$ - patients receiving basic therapy, mucolytic therapy - a combination of Ambroxol and acetylcysteine - 200/30 to 1 tabl. 2 times a day, number 7 days and, from the 3rd day - sessions of halotherapy 1 time per day № 10. The second group, the control group ( $\mathrm{n}=30)$, followed only basic therapy, did not take mucolytics and halotherapy sessions.

Results: Patients receiving therapy with the combination of ambroxol and acetylcysteine and halotherapy sessions experienced a significant increase in FEV1 by $8.3 \%$ $(p<0.05)$; the Tiffon index was $7.2 \%(p<0.05)$, reactive anxiety levels $(R A)$ and manifestations of autonomic dysfunction decreased, whereas in patients in the control group these indicators did not improve significantly.

Conclusions: The proposed complex therapy of COPD patients with the inclusion of the combined drug ambroxol and acetylcysteine and halotherapy sessions contributes to the improvement of the quality of life of patients.
\end{abstract}

KEY WORDS: chronic obstructive disease of lungs (COPD), halotherapy

Wiad Lek. 2020;73(4):773-776

\section{INTRODUCTION}

To date, chronic obstructive pulmonary disease (COPD) remains one of the biggest health problems, according to WHO, the disease affects $0.8 \%$ of the world's population, as of 2030, according to experts' forecasts, will be the third leading cause of death in the world [1.2.3]. A significant prevalence of COPD, an increase in the level of disability in working age, inadequate effectiveness of existing treatment and prevention methods, necessitates the development of new ways to optimize treatment [1].

Considering the significant place of transport violations of the tracheo-bronchial secretion in the formation of respiratory diseases, one of the main tasks of therapy is the sputum dilution, reducing its adhesiveness and improving the drainage properties of the respiratory tract. A promising direction is the use in one dosage form of a combination of several agents at once that affect various pathogenetic mechanisms of violation of the production of a secret in the tracheobronchial tree. The combination of these properties in one drug contributes to more effective improvement of mucosylial clearance and simultaneous reduction of clinical symptoms, as well as increased adherence to therapy, which is especially relevant in outpatient practice. Optimal correction of the most important violations in secretion of bronchial glands, restoration of the adequacy of drainage functions of the respiratory tract, in our opinion, determines the combination of ambroxol and acetylcysteine. Among the many drugs with simultaneous mucolytic and muco-regulating effects used in the treatment of infectious-inflammatory diseases of the respiratory system in adults and children, the PulmoBRIZ drug, which includes ambroxole hydrochloride and acicillin, showed high therapeutic effectiveness [4].

It should be noted that in recent years, in the rehabilitation of patients with COPD, the method of halotherapy simulating the microclimate of salt mines is widely used [5]. Halotherapy promotes increased resistance of the body to negative external factors, including psycho-emotional stress, prevention of colds. Also known as anti-inflammatory and immunomodulatory effects of aeroion sodium chloride [5.6]. When the respiratory fraction of aerosol hits the terminal parts of the bronchial tree, due to the osmotic effect, the activation of the drainage function of the bronchi occurs, increases the amount of detachable sputum. On the one hand, it helps to eliminate one of the components of broncho-obstruction, and on the other - significantly increases the effectiveness of basic drug therapy. All this contributes to the positive dynamics of clinical indicators in patients with COPD and the consolidation of achieved remission [1].

\section{THE AIM}

The aim is to increase the effectiveness of the treatment of exacerbation of COPD group B GOLD II with the use of combined therapy of the combined drug PulmoBRIZ 
containing two components - ambroxol and acetylcysteine and the course of halotherapy.

\section{MATERIALS AND METHODS}

We observed 60 patients with COPD B, GOLD II. The average age of patients was $47,8 \pm 2,4$ years. The diagnosis was exposed in accordance with the order of the Ministry of Health of Ukraine 555 dated June 27, 2013, based on a comprehensive examination. The assessement of the symptoms of the disease, the results of laboratory and instrumental research methods (blood tests, sputum, chest X-ray, external respiration function (ERF), bronchodilation tests was carried out. All patients received therapy in accordance with the protocol for assisting patients with COPD [7.8].

Patients with COPD were divided into two groups: the first - the main $(\mathrm{n}=30)$ received complex basic therapy: clarithromycin $500 \mathrm{mg}$ twice daily, tiotropium bromide for 1 breath 2 times a day, budesonide 50 micrograms through a nebulizer two times a day for 7 days. Additionally we prescribed the combined preparation of Ambroxol and Acetylcysteine (Pulmobreathe) - 200/30 to 1 tabl. 2 times a day for 7 days, and from the 3rd day were added halotherapy sessions. We have used the IONNA halogen generator in the mode (ionizer $30 \pm 50 \%$ capacity, volume of air flow $15 \pm 20 \mathrm{~m}^{3} / \mathrm{h}$, temperature in the chamber $40 \pm$ $50^{\circ} \mathrm{C}$, duration $40 \pm 60 \mathrm{~min}$.) 1 time per day for 10 days.

The second group - is a control $(n=30)$, followed only basic therapy. This group has not taken mucolytics and halotherapy sessions during all time of treatment.

The effectiveness of treatment was evaluated in both groups according to the dynamics of reduction of clinical symptoms of COPD, changes in laboratory, instrumental and functional research methods. Before treatment, and after 12 days, the ERF parameters were analyzed, the symptoms were evaluated using questionnaires - Modified MRC Dyspnea Scale (mMRC) and COPD Assessment Test (CAT) [7]. Psychological status was determined with the help of questionnaire Ch.D. Spielberger - Yu.L. Hanin and was evaluated in points by the following criteria: up to 30 points - low anxiety; 31 - 45 - average; 46 or more - high anxiety [9.10].

Data from clinical and laboratory research were statistically processed by Student's criterion. $\mathrm{p}<0,05$.

\section{RESULTS}

Before treatment, all patients noted an increase in cough with purulent sputum, shortness of breath under physical activity, fever to subfebrile digits, general weakness.

In a survey on the scale of mMRC in patients with the main group, the average indicator was $2.6 \pm 0.5$ points, indicating exacerbation of COPD, whereas after treatment $0.6 \pm 0.4$ points $(\mathrm{p}<0.05)$. In patients in the control group receiving baseline therapy, the average score of the total points before treatment was $2.48 \pm 0.7$, after treatment $0.9 \pm 0.3(\mathrm{p}<0.05)$.

The total index of CAT in patients of the main group before treatment was $18.3 \pm 1.1$ points, after treatment -
$6.4 \pm 0.4$ scores $(\mathrm{p}<0.05)$, in patients of the control group before treatment $-19.1 \pm 1.4$ scores, after treatment $10.1 \pm 0.3(\mathrm{p}<0,05)$. Thus, according to the questionnaire CAT, after the treatment, significant differences $(\mathrm{p}<0.05)$ between patients in the main and control groups were noted, indicating the effectiveness of complex therapy of exacerbation of COPD.

In the course of treatment, the evaluation of the regression of the main clinical symptoms was performed in patients with the main and control group. There were significant differences in terms of the disappearance of shortness of breath, cough $(\mathrm{p}<0.05)$. The average cough loss in patients with the main group was $4.6 \pm 0.32$ days, whereas in the control group $-5.9 \pm 0.44$ days $(\mathrm{p}<0.05)$. The average duration of dyspnea disappearance in patients in the main group was $3.5 \pm 0.26$ days, whereas in patients with control group $-4.7 \pm 0.53(\mathrm{p}<0.05)$. The results obtained are shown in Figure 1.

Thus, regression of the main symptoms of COPD cough, shortness of breath was observed in shorter time in patients with the main group receiving complex therapy, indicating its effectiveness.

In the study of EFR, it was noted that in the patients of the main group receiving the combined drug ambroxol and acetylcysteine and halotherapy in addition to the basic therapy, a significant growth of $\mathrm{FEV}_{1}$ was observed at $8.3 \%(72.5 \pm 1.1) \%$ to $(79.1 \pm 1.8) \%(\mathrm{p}<0.05)$; the growth of the $\mathrm{FEV}_{1} / \mathrm{FVC} \%$ was $7.2 \%(72.3 \pm 1.4) \%$ to $(77.6 \pm 1.9) \%(\mathrm{p}<0.05)$, while in the control group, the growth of $\mathrm{FEV}_{1}$ was noted at $5.5 \%$ - from $(71.7 \pm 1.6) \%$ to $(75.7 \pm 1.2 \%)(\mathrm{p}>0.05)$; the of $\mathrm{FEV} / \mathrm{FVC}$ o was $4.6 \%$ - from $(71.2 \pm 1.3$ to $(74.5 \pm 1.9)(p>0.05)$, that is, these indicators only tended to improve. The results are presented in Table 1 .

Thus, using in combined therapy for patients with COPD of the combined drug PulmoBRIZ with simultaneous mucolytic and mucorregulatory action and the course of halotherapy, contributes to the significant elimination of broncho-obstruction, as evidenced by a significant $(\mathrm{p}<0,05)$ increase in the rates of $\mathrm{FEV}_{1}, \mathrm{FEV}_{1} / \mathrm{FVC}$ after the course of treatment in patients the main group.

Examination the psychological state of patients with COPD, using the questionnaire - Ch.D. Spielberger - Yu.L. Hanin in patients with COPD revealed an increased level of reactive anxiety (RA). Thus, in patients with the main group, the average level of RA before treatment was 46.1 \pm 2.12 , in the comparative control group it was $45.6 \pm 2.8$. Dynamics of indicators of reactive anxiety, personal anxiety during the treatment of patients in the main and control groups is given in Table II.

From the data provided, it is shown that after the treatment, significant reduction of RA and manifestations of autonomic dysfunction in the group of patients, which additionally received the combined preparation ambroxol and acetylcysteine and halotherapy sessions, were noted. Thus, the average level of RA in patients of the main group before treatment was $46.1 \pm 2.12$ points, after treatment $30,3 \pm 2,43$ - decreased by $34,2 \%(\mathrm{p}<0,05)$. In patients in the 


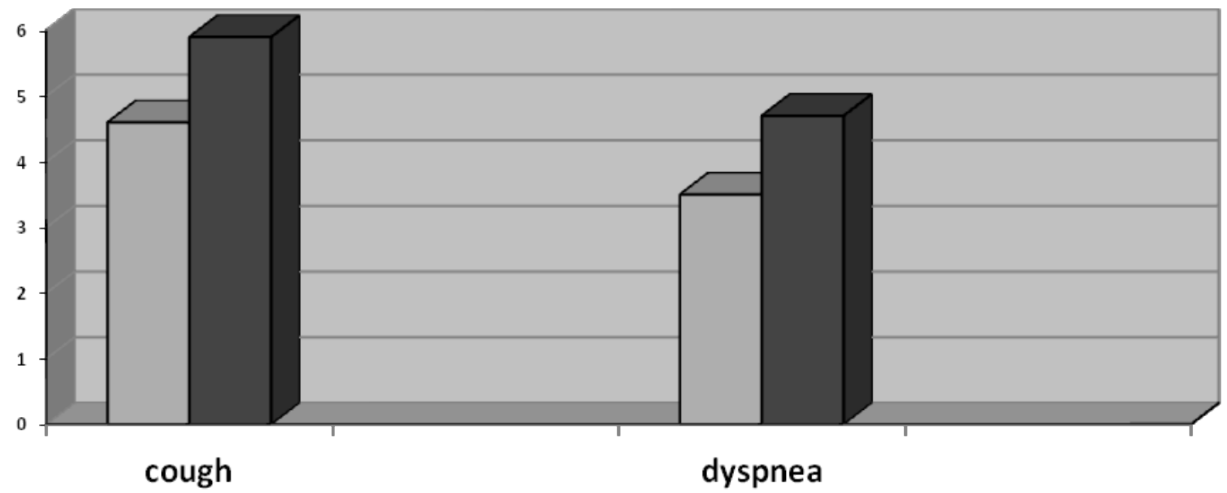

$\square$ main group

$\square$ control group

Fig. 1. Average terms of disappearance of cough, shortness of breath in patients with the main and control groups

Table I. Dynamics of indicators of the function of external respiration in the process of treatment

\begin{tabular}{|c|c|c|c|c|}
\hline \multirow{2}{*}{ Indicator, unit } & \multicolumn{2}{|c|}{ Main group $(n=30)$} & \multicolumn{2}{|c|}{ Control group $(n=30)$} \\
\hline & Before treatment & After treatment & Before treatment & After treatment \\
\hline VC, \% & $73.1 \pm 1.3$ & $79.6 \pm 1.2$ & $72.4 \pm 1.9$ & $75.9 \pm 2.2$ \\
\hline $\mathrm{FEV}_{1}, \%$ & $72.5 \pm 1.12$ & $79.1 \pm 1.85^{*}$ & $71.7 \pm 1.6$ & $75.7 \pm 1.2$ \\
\hline FEF25,\% & $68.3 \pm 1.6$ & $69.2 \pm 1.42$ & $62.8 \pm 2.1$ & $65.6 \pm 1.9$ \\
\hline FEF50,\% & $62.2 \pm 1.4$ & $66.1 \pm 1.8$ & $62.1 \pm 1.4$ & $64.22 \pm 2.1$ \\
\hline FEF75,\% & $61.4 \pm 1.7$ & $64.3 \pm 1.9$ & $61.7 \pm 1.8$ & $61.3 \pm 1.2$ \\
\hline $\mathrm{FEV}_{1} / \mathrm{FVC} \%$ & $72.3 \pm 1.4$ & $77.6 \pm 1.9 *$ & $71.2 \pm 1.3$ & $74.5 \pm 1.9$ \\
\hline
\end{tabular}

Note: ${ }^{*}(p<0,05)$ - the differences are reliable before and after treatment

Table II. Dynamics of indicators of reactive and personal anxiety in the process of treatment in patients with the main and control groups

\begin{tabular}{ccccc}
\hline \multirow{2}{*}{ Group of patient } & \multicolumn{2}{c}{ Reactive anxiety } & \multicolumn{3}{c}{ Personal anxiety } \\
\cline { 2 - 6 } & Before treatment & After treatment & Before treatment & After treatment \\
\hline main $(n=30)$ & $46.1 \pm 2.12$ & $30.3 \pm 2.43$ & $42.1 \pm 3.12$ & $40.3 \pm 2.45$ \\
\hline control $(n=30)$ & $45.6 \pm 2.8$ & $37.5 \pm 3.2$ & $40.8 \pm 3.32$ & $39.3 \pm 3.02$ \\
\hline
\end{tabular}

Note: ${ }^{*}(p<0,05)$ - the differences are reliable before and after treatment.

control group, the RA level before treatment was $45.6 \pm 2.8$ after treatment $37.5 \pm 3.2$ - decreased by $17.7 \%(\mathrm{p}>0.05)$. There was no significant difference in the rates of personal anxiety after treatment between the groups.

\section{DISCUSSION}

The high level of RA was manifested by a feeling of psychoemotional tension, irritation, dissatisfaction with oneself and the environment. Under psychosomatic disorders, most leading scientists understand the group of disease states that arose on the basis of the interaction of mental and somatic factors manifested somatization of mental disorders, mental disorders that cause a response to a somatic disease, or the development of somatic pathology under the influence of psychogenic factors [11]. Thus, in addition to the etiological and pathogenetic factors affecting the quality of life (LQ) of the patients with COPD, the presence of a concomitant clinically significant syndrome the RA increases the negative effect on all components of LQ of these patients, which coincides with the authors' opinion [10]. The obtained results suggest that reactive anxiety is a very mobile feature and is characterized by reversibility in normalizing the somatic state and social conditions of man [9]. Thus, application in patients with COPD in the complex treatment of the course of halotherapy, does not only effect the bronchodraining, sanogenic, anti-inflammatory effects, but also helps to reduce reactive anxiety, which coincides with the opinion of specialists [6].

The observation dynamics showed that in patients with the main group receiving complex therapy, COPD exacerbations were not observed for 6 months, while in the control group - 4 (16\%) patients had a recurrence of the disease. During the study, on the background of therapy with a gentle course of 12 days, no any adverse events from other organs and systems were registered. 


\section{CONCLUSIONS}

Thus, the complex therapy of patients with COPD, with the inclusion of the combined drug "Pulmobreathe" and the sessions of halotherapy, contributes the regression of the main clinical manifestations of the disease in a shoter time, significant improvement in the function of external breathing, reducing the level of reactive anxienty and prolonging the duration of remission, all of which improve patients' lives.

Complex therapy of patients with COPD with the inclusion of a combined drug "Pulmobreathe" and the course of halotherapy characterized by improvement of the course of the disease due to: significant reduction of clinical symptoms;

improvement of bronchial patency rates;

decrease of the reactive anxienty level;

no any complications.

Prospects for further research. Study of indicators of ERF, psychological state of quality of life of patients with COPD in more distant periods of observation - in 1 year.

\section{REFERENCES}

1. Potiazhenko M.M., Ishcheikin K.le., Nastroha T.V., et al. Zastosuvannia ratsionalnoi kompleksnoi terapii pry infektsiinomu zahostrenni khronichnoho obstruktyvnoho zakhvoriuvannia lehen. [The use of rational combination therapy of the infectious exacerbation of COPD] Liky Ukrainy 2016;10(206):79-83.(UA).

2. Zhdan V.M., Khaimenova H.S., Ivanytskyi I.V., et al. Otsinka dynamiky klinikolaboratornykh pokaznykiv u likuvanni khvorykh na khronichne obstruktyvne zakhvoriuvannialehen upoiednannizosteoartrytom. [Assessmentofdynamics of clinical and laboratory parameters through the treatment of patients with chronic obstructive pulmonary disease and comorbid osteoarthritis] Aktualni problemy suchasnoi medytsyny. 2017;17(2 (58):129-131. (UA).

3. Prykhodko N.P., Hopko 0.F. Otsinka yakosti zhyttia u patsiientiv z khronichnym obstruktyvnym zakhvoriuvanniam lehen v poiednanni z kardiovaskuliarnoiu patolohiieiu [Quality of life in patients with chronic obstructive pulmonary diseases and comorbid cardiovascular diseases / Aktualni problemy suchasnoi medytsyny. 2015; 15(2(50):123-126. (UA).

4. Kochuev H.Y., Kochueva M.N., Korzh A.N. Mesto mukolytykov v kompleksnoi terapyy vospalytelnykh zabolevanyi dykhatelnykh putei. [The Place Of Mucolytics In the treatment of In ammatory Respiratory Diseases] Skhidnoievropeiskyi zhurnal vnutrishnoi ta simeinoi medytsyny.2017;1:102-107.( Ru).

5. Deineha V.I., Kryvenko V.H., Voloshyna I.M. Fizioterapiia i vidnovne likuvannia v praktytsi simeinoho likaria. [ Physiotherapy and rehabilitation in the practice of a family doctor] Zaporizhzhia 2014. 296 s. (UA).

6. Lemko 0.I. Lemko 0.S. Speleoterapiia, halo terapiia, haloaerozolterapiia: definitsii, mekhanizmy vplyvu, perspektyvy vykorystannia. [Speleotherapy, halotherapy, haloaerosoltherapy: definitions, mechanisms of influence, perspectives of usage (part I)] Astma ta alerhiia.2017;3:50-63. (UA).

7. Nakaz MOZ Ukrayiny” vid 27.06.2013 № 555 “Pro zatverdzhennya ta vprovadzhennya medy 'ko-texnologichny' $x$ dokumentiv zi standarty'zaciyi medy' chnoyidopomogy' pry' xronichnomu obstrukty' vnomuzaxvoryuvanni legen " " [Order of the Ministry of Health of Ukraine No. 555 of June 27, 2013 "On Approval and Implementation of Medical-Technological Documents on Standardization of Medical Assistance in Chronic Obstructive Pulmonary Disease"] http://old.moz.gov.ua/ua/portal/dn_20130627_0555.html (UA).
8. Global Initiative for Chronic Obstructive Lung Disease (GOLD) The Global Strategy for tre Diagnosis, Management, and Prevention of Chronic Obstructive Pulmonary Disease (2019 report) www.goldcopd.org.

9. Nastroha T.V. Osoblyvosti terapii khvorykh pokhyloho viku z komorbidnoiu patolohiieiu - na arterialnu hipertenziiu u poiednanni iz suputnim khronichnym obstruktyvnym zakhvoriuvanniam lehen. [ Features of therapy of elderly patients with comorbidity - arterial hypertension and concomitant chronic obstructive pulmonary disease ] Problemy ekolohii ta medytsyny. 2017; 21( 1-2):14-17. (UA)

10. Dovhan A.O., Konstantynovych T.V. Otsinka yakosti zhyttia khvorykh na khronichne obstruktyvne zakhvoriuvannia lehen za suputnikh rozladiv psykhoemotsiinoi sfery [Assessment of the quality of life of patients with chronic obstructive pulmonary disease in concomitant disorders of the psycho-emotional sphere] Scientific Journal «ScienceRise: Medical Science» 2017; 5(13):36-41. (UA).

11. Kharchenko D.M., Izviekova 0.lu. Faktory vplyvu na rozvytok psykhosomatychnykh rozladiv [Factors of influence the development of psychosomatic disorders ] Teoriia i praktyka suchasnoi psykholohii 2018;4: 80-84.(UA).

The work is a fragment of the initiative research work "Development of algorithms and technology for introducing a healthy lifestyle in patients with non-communicable diseases based on the study of psycho-emotional status". The number of state registration 0116 U007798.

\section{ORCID and contributionship:}

Maksym M. Potyazhenko - 0000-0001-9398-1378 ${ }^{F}$

Kostiantyn Ye. Ishcheikin - 0000-0001-7887-0995 C

TetianaV. Nastroga - 0000-0001-5347-6094 ${ }^{D}$

Nina L. Sokolyuk - 0000-0002-7436-9965 ${ }^{E}$

Oksana Ye. Kitura - 0000-0001-5319-5831 ${ }^{\text {A }}$

Inesa M. Gorodnytska - F0000-0002-5550-4666 ${ }^{B}$

\section{Conflicts of interest:}

Authors declare no conflict of interest.

\section{CORRESPONDING AUTHOR Tatjana V. Nastroga}

Department of Internal Medicine and Emergency Medicine

Ukrainian Medical Stomatological Academy

Shevchenko street, 23, Poltava, Ukraine

tel: +380664257211

e-mail: umsainua@ukr.net

Received: 04.07 .2019

Accepted: 18.02 .2020

A - Work concept and design, B - Data collection and analysis, C - Responsibility for statistical analysis, D -Writing the article, E-Critical review, $\mathbf{F}$ - Final approval of the article 